\title{
The Incubation Process and the Strengthening of the Firm: a Study in Brazilian Companies
}

\author{
Guillermo Cruz', Caroline Prates², Priscila Silva Esteves ${ }^{3}$
}

\begin{abstract}
High mortality rate and an environment in constant change set up a context in which the search for innovation becomes essential to business' longevity. Incubation has been proposed as an alternative to start-up companies, giving support for their development. Seeking to explore which characteristics enable a firm's development through incubation, a multiple case studies were performed. Interviews were carried out with two Incubated, and three Graduated companies. Results indicate that the incubation process is important to strengthening of the firm. This was observed when innovative strategies employed by companies were analyzed. It was noted an evolution from Incubated to Graduated. During the incubation process, the companies showed a greater focus on strengthening their knowledge bases, seeking to establish qualification relationships and invest in an innovation strategy based on better human resources allocation while the Graduated ones attempt to achieve further innovation by structuring and coupling their own commercial and R\&D departments.
\end{abstract}

Keywords: incubation process; firm; innovation; networks; resources; technology companies.

I,2,3 Management School, Federal University of Rio Grande do Sul PPGA/EA/UFRGS. Rua Washington Luiz 855, Porto Alegre, RS 90.010-000. Brazil. Phone: +55 (5I) 3308 3536. E-mail: 'guillermo.cruz@ufrgs.br.

ISSN: 07 I8-2724. (http://www.jotmi.org) 


\section{Introduction}

Early in its existence enterprises are faced with a question that will follow them for the rest of their lives: how to survive in an increasingly competitive and uncertain market? The solution to this question is far from simple, and may involve both internal (structure, the distribution of its physical and human resources, knowledge management, etc.) and external aspects of the company (rules, norms, beliefs, or even consumer preferences).

Data on survival rate of companies underscore the complexity around this issue. In some countries, such as the United Kingdom, considering companies created in 2007, the survival rate which is $95.4 \%$ in the first year drops to $63.0 \%$ in the third year (ONS, 20I2), behavior similar to North American companies established in the same year which have $100 \%$ chance of survival in the first year and $63.4 \%$ after the third year of operation (U.S. Department of Labor, 2012). A somewhat different reality is found in Brazil, where businesses have a survival rate of $76.1 \%$ in the first year, decreasing to $51.8 \%$ in the third year (Figure I).

Despite being significantly lower, survival rates of Brazilian companies has been increasing each decade. According to the Brazilian Institute of Tax Planning $15.41 \%$ of the ventures dies within the first year of life while $41.86 \%$ of the enterprises disappear between the first and fifth year of existence (IBPT, 2012). In the 70s, the rate of disappearance of firms in the first year of life was almost double, $29.15 \%$, and $59.81 \%$ of the ventures ended their activities after five years.

In the past decades there has been an increasing in the number of incubators operating in Brazil (Figure 2). These organizations were created with the purpose of prepare new companies to compete both inside and outside the country (Celta, 20I I), by strengthening their products and relation-

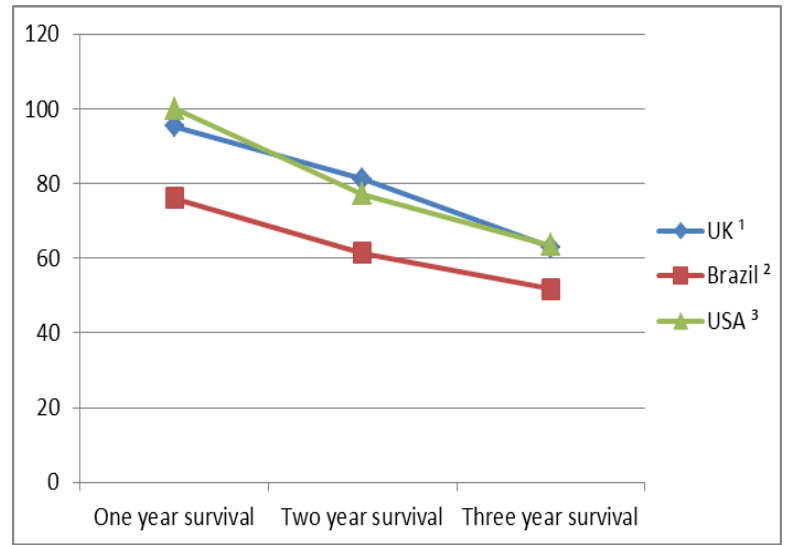

Figure I. Survival rates for businesses born in 2007. Data from: ' ONS (20I2); ${ }^{2}$ U.S. Department of Labor, Bureau of Labor Statistics (20I2); ${ }^{3}$ IBGE (20I2). ships with the market through university-enterprise interactions, where the university works as an agent responsible for transference of knowledge and technology to Incubated companies (Abib, et. al., 2007). The National Business Incubation Association (NBIA, 20II), for example, defines the incubators as an instrument designed to accelerate the growth and success of new enterprises by providing business support services and resources. Companies that are in the incubation process are called "Incubated" and those that have gone through this stage - which takes on average two years, are entitled "Graduated" I. The incubators are represented by the Associação Nacional de Entidades Promotoras de Empreendimentos Inovadores (ANPROTEC), which also represents all businesses that utilize the incubation process to generate innovation in Brazil. Beyond representing the incubators, ANPROTEC also does regular monitoring and evaluation of incubators' activities. The association has recently asserted that the mortality rate of companies which have gone through the incubation process is $20 \%$, being significantly lesser than national levels (ANPROTEC, 2006). But, would this growing number of incubators somehow influencing the decrease in mortality observed in Brazilian companies in recent decades? What characteristics of the incubation process could be influencing the high survival rate of companies that go through this process?

To survive in a competitive environment, it becomes essential for companies to remain in a constant state of creation, by developing "new combinations" (Schumpeter, 1997) or, put simply, through innovations. Such innovations may originate from research and development activities within organization (Freeman and Soete, 2008), where product or process innovations may occur by the introduction of new methods, techniques, materials or types of equipment and also as a result of the flow of information (or knowledge) engaged in manufacturing a new product or offering a new service (Tidd, et. al., 2008). Innovations can also arise from

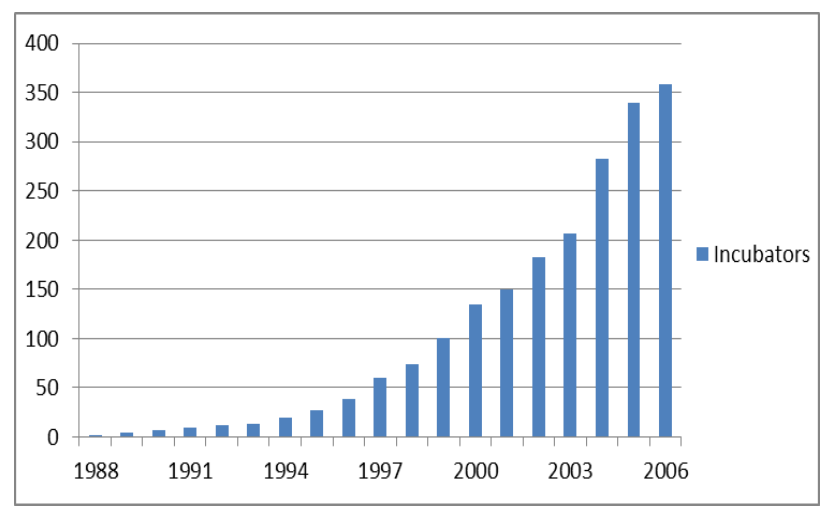

Figure 2. Number of incubators operating in Brazil. Data from ANPROTEC (2006).

ISSN: 07 I8-2724. (http://www.jotmi.org)

Journal of Technology Management \& Innovation (c) Universidad Alberto Hurtado, Facultad de Economía y Negocios. 
how organization benefits from competitors and related industries, where the company can assume a position of follower or copier of what other organizations have invented first (Afuah, 2003). In this respect, innovation activity could both be restricted to the national context, as to the international, when innovation may be obtained through imitation of innovations from other countries (Kim, 1997). But, can innovation be stimulated through the incubation process?

For some authors, such Enriquez (200I) incubators could be an example of "innovation systems", generating, importing, modifying and diffusing new technologies, having innovation as one of its crucial aspects. There are some authors, such Etzkowitz, Mello and Almeida (2005), however, who do not consider the incubators as "promoters" of innovation, but instead views the incubation process as an educational activity involving an expansion of the academic educational mission from training individuals to educating organizations. At this point, it may be relevant the contribution of the literature which explores how companies seek to gain competitive advantage through construction and development of its "capabilities".

There are different definitions regarding the concept of capabilities in literature. Nelson and Winter (1982), for example, defined them as a set of routines on an enterprise, which may be considered as "skills of an organization" (Dosi, Nelson and Winter, 2000), i.e. know-how that enables organizations to perform its activities (Leonard-Barton, 1992). Other authors have identified them as "distinctive" or "core" competencies (Selznick, 1957; Prahalad and Hamel, 1990) which are fundamental to the dynamics of the firm's competitive strength, lending strategic coherence to a variety of new and improved products appearing over a period of time. Pointing in the same direction, some authors propose the concept of "dynamic capabilities" (Teece, Pisano and Shuen, 1997; Eisenhardt and Martin, 2000) concerning the ability of an organization to cope with its internal and external competences in order to address rapidly changing environments. Considering this, what capabilities would have being developed in the enterprises through the incubation process? Could this development have some kind of influence in the innovation capability of Incubated and Graduated companies?

Another important issue for innovation is the firm concept. The firm was defined by Coase (1937) as an economic agent that did not need to have its transactions regulated by the market, and its production directed by the "entrepreneurcoordinator," which shall have primary responsibility for finding alternative forms of organization to escape from transactional costs. From this, it is important for firms to develop products that have added value through innovation and developing its capabilities. But, could the incubation process strengthen the firm?
In order to explore this and the previous questions, this study aims to measure the contribution of the incubation process considering as study object Incubated and Graduated companies. The research was conducted with firms situated in the State of Rio Grande do Sul, located in southern of Brazil.

We expect with this research contribute with academic literature focused on the business incubation process and help to understand the specificities resulting from this process that contribute for an improved business performance. Pragmatically, we expect to assist incubators in obtaining better practices and in identifying those that are not going right in the incubation process.

This article was structured in the following way: in Section 2 we present briefly the theory of the firm and the innovation process. Research methodology is demonstrated in Section 3. Section 4 presents the results, and finally, concluding remarks are discussed.

\section{The Firm and the Innovation Process}

One can consider the firm as a technical-economic agent that produces goods and services and moves in the market operating an organizational structure at a minimum cost that should change over time through internal and external forces. The main objective of a firm is to fill a knowledge gap in the market and, therefore, to continue operating in the chosen environment, it should produce a different solution that must be recognized as such by the consumer (Zawislak, et. al., 20I2).

From this, it appears that the firm is a knowledge and learning agent.Amendola (1983) presents this idea to say that one should not reduce the production process to an ordinary combination of factors, "petrified" in specific equipment, in which the company is seen as the place of processing raw materials into final products. It must be primarily identified by its ability to continuously change its own structure instead, in order to adapt itself to the context in which it lives and should grow.

For Nelson and Winter (1982), the generation and application of new technologies would come from initiative and effort of firms themselves in this adaptation process to the assets of the institutional environment. According to Zawislak (2004), from specific knowledge (routines or "genes") and perception (based on the ability and the limited rationality of the managers), firms would have technological expertise to ensure their survival in adverse and competitive situations. This competence, according to the author, would be based on an internal capacity to change the combination of factors in a specific way ("mutation") to search for extraordi- 
nary gains in the market. From this and the clash of different technologies (generated from different firms) in the market, there would be a true "natural selection". From this process, called "gene-mutation-selection", the greater essence of economic and technological development was born, in which Nelson and Winter (1982) give the firm the role of economic development engine.

In reviewing literature concerning the firm, it is possible to identify two approaches: on one hand, there are researchers who see the firm as a set of resources, knowledge, experience, skills and routines (Penrose, 1959; Richardson, 1972; Nelson and Winter, 1982) and on the other hand, there are those who see it as a nexus of operating agreements according to certain ways of governance (Coase, 1937; Williamson, 1985). For Coase (1937), the origin of firms, far from being random and having little understandable presence, it is at times shown in the market inefficiency. This means that, considering the market's inefficiency, the cost of going to the market for acquiring some good or service is not always less than the cost of organizing the production inside the firm.

\section{I The firm}

According to Coase (1937) there would be a series of transactions that could be organized within the firm without generation of the typical "friction" to go to the market to know what the best price for the alleged transaction. Coase (1937) called this friction transaction costs. Furthermore, the same author says that firms exist because of the costs involved in conducting determined market activities. In many situations, the cost of acquiring an asset in the market is higher than the actual price of this asset, since this acquisition also involves other costs such as: research, negotiating and maintenance of trade secrets (Marins, 2007).

Therefore, to Coase (1937), there are several transactions that can and should be developed within the firm because "it is cheaper for the firm to carry out their activities internally than to go to the market and perform a search for them, since the process of going to the market may represent higher transaction costs" (Marins, 2007, p. 3). In this context, there is a very important figure: the entrepreneur-coordinator (Coase, 1937). He has the role of finding alternative forms of organization to escape from transaction costs.

In addressing transaction costs, Williamson (1985, 1996) states that transaction costs are consequences of institutional events (e.g., customer profiling, market structures, culture, legislation, etc.), for which the assets that a company has may be more or less adaptable. Thus, the more adaptable, the lower their transaction costs.
In this context, it is important note that the condition for a company become a firm is that it should have specific knowledge which will be applicable to bring valuable solutions (goods and services) with some potential to be sold (Zawislak, et. al., 20I2). When a manufacturer acquires a particular knowledge from its kindred providers, what they need to do then is not only keep them up, but to make them more profound and valuable. The company may legally exist, but to become a firm, it has to solve the problem of value. That is, to deliver the most value to consumer at the lowest cost (Langlois, 2003).

\subsection{The innovation process and the firm's survival}

As presented, it was Coase (1937) who started the first discussions about the importance of firms in market configurations, by establishing that if only prices were the drivers of production - coordinated through a series of exchanges with the market - there would be no difference among firms in this environment. One way to analyze the difference of firms in the market is brought to the discussion by Schumpeter (1997) which states that their success and survival were directly related to its ability to innovate.

In the literature there are many and varied approaches to the term "innovation". Joseph Schumpeter, a pioneer in innovation studies, lastly identified it from the term "development", considering it to be changes in economic life "that were not imposed by the outside, but that came up from within by its own initiative" (p. 74), having as its fundamental process "the realization of new combinations" (p. 76). Here we have the important role played by the "entrepreneur": an agent of innovation responsible for carry out economic development.

Following Schumpeter's first contributions on innovation, some authors have identified it as a key element for firm's survival (Nelson and Winter, 1982; Freeman and Soete, 2008), a "pioneer activity" (Kim, 1997) essential for the renewal of the organization and maintenance of its growth potential (Bessant, et. al., 2005), or yet as a "new combination of knowledge" in the generation of a new knowledge that has an exchange value (Zawislak, 1995). It is also possible to identify what is an "innovation" through a comparison with "inventions". While an invention characterizes the first occurrence of an idea for new products or processes, innovation is related to the first attempt to carry it out into practice (Fagerberg, 2005). This means that in order to turn and invention into an innovation, firms must have to combine several different types of knowledge, capabilities, skills, and resources. In other words, enabling innovation is a task to be undertaken both internally and externally by the firm. Externally, by having access to a more varied set of activities, experiences, and collaborators, companies could increase 
their resource and knowledge base (Powell and Grodal, 2005). The literature on innovation has emphasized that the firm does not innovate in isolation, but does so through extensive interaction with its environment (by participating in different "networks"). In this case firms could cultivate both strong and weak ties (Granovetter, 1973). Through strong ties the firm gets a type of information that is detailed, rich and "thick", but with little or none novelty, what may restrict information gathering in terms of the breadth of search. On the other hand through weak ties the firm could have access to non-redundant information, what can be useful for innovative firms maintain their capacity for changing its orientation, even that ties like these are thinner and less durable than the strong ones (Powell and Grodal, 2005). Hence, cultivating the capacity for absorbing (outside) knowledge, or an "absorptive capacity" is essential for innovative firms (Cohen and Levinthal, 1990).

Internally, an important factor is the firm's capabilities. Some have considered it as the "routines" of an organization (Nelson and Winter, 1982), others have talked about it as "core capabilities" (Leonard-Barton, 1992), or yet "core competences" (Prahalad and Hamel, 1990) representing the knowledge set that distinguishes and provides a competitive advantage to firms. Still, there are authors who purpose the concept of "dynamic capabilities" (Teece, Pisano and Shuen, 1997), which can be viewed as "simple, experiential, unstable processes that rely on quickly created new knowledge and iterative execution to produce adaptive, but unpredictable outcomes" (Eisenhardt and Martin, 2000, p. 1006). Here it will be considered both processes, knowledge and the resources involved in firm's innovation processes as its capabilities. In other words, the "skills" of the firm (Dosi, Nelson and Winter, 2000).

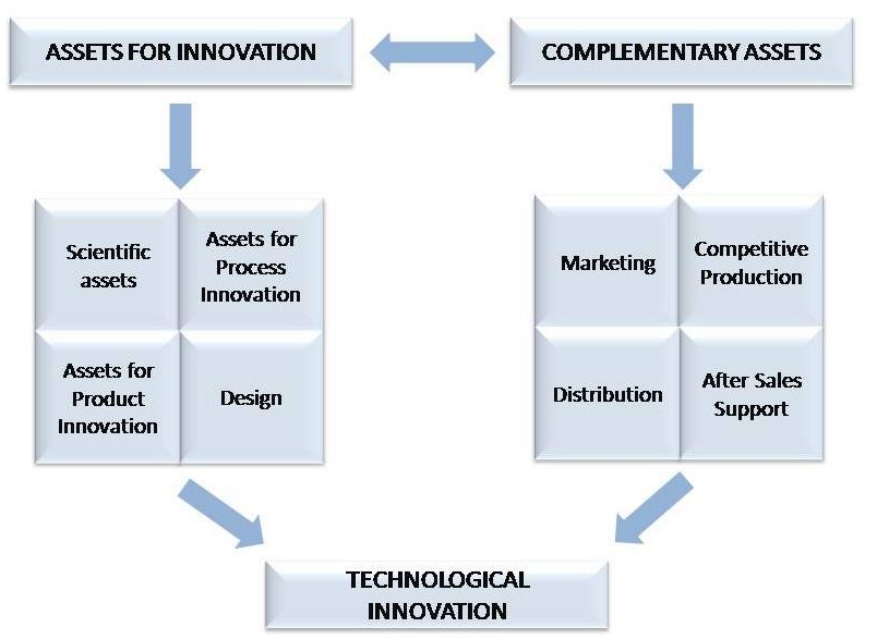

Figure 3. Determinants of technological innovation. Data adapted from Cabral (200I; 2007)
Whether by the use of its capabilities or its relations in complex networks, innovative firms are constantly performing a bilateral or interactive activity. On one hand, it will be regularly looking for consumer needs - or a potential market for a new product -, and on the other, it will be developing research activities involving technical and scientific knowledge, for example, an R\&D department (Freeman and Soete, 2008). Cabral (200I; 2007), for instance, based on Teece (1986) and Christensen (1995), has developed a conceptual framework for assessing technological innovation's determinants (Figure 3).

According to this approach, technological innovation does not require efforts only in research and development (R\&D), it also requires the use of different "complementary assets" (Christensen, 1995). It is necessary not only investment in R\&D, but also the successful innovation commercialization, which requires the complementary assets for the initial innovation development (Teece, 1986; Cabral, 200 I; 2007).

In this regard, during the technological innovation process, two parallel activities occur: the R\&D and commercial. At first, the firm should use: (I) scientific assets, which involves researching; (2) innovation process assets, which includes both the instrumental and the structural part; (3) product innovation assets; and (4) design, which have the function to connect the technical features with marketing (Christensen, 1995; Cabral, 200 I; 2007). In the commercialization process, in turn, it must use the complementary assets related to typical activities of business functional areas, such as marketing, distribution, sales support and competitive production (Teece, 1986; Cabral, 200 I; 2007).

As discussed above, in order to the firm exists, it is necessary to transact with the market. Thus, firms will be more effective in their innovative activities once they can leverage their efforts in R\&D and commercialization of their innovations. As noted by Cabral (2007) in his study of the Brazilian food industry, alliances between the firms, research agencies, institutions or universities may result in a better technology use and market opportunities, in addition to increasing the "firm innovative intensity". At this point, business incubators can play an important role.

\section{Research Procedures}

The present study consists in a qualitative research, through multiple case study.According to Bonoma (1985), this method is appropriate when the objective is to construct theories, since it provides a deeper understanding of the phenomenon within its own context. According to Yin (2010), this is a potential method of research when you want to understand a complex social phenomenon, because it assumes a greater level of detail of the relationship between indi-

ISSN: 07 I8-2724. (http://www.jotmi.org)

Journal of Technology Management \& Innovation (c) Universidad Alberto Hurtado, Facultad de Economía y Negocios. 
viduals and organizations, as well as the exchanges that take place within the environment in which they are inserted.

Primary and secondary data were used for the research. As a source of primary data we use semi-structured interviews, which are characterized by the use of an interview guide in which the researcher has freedom to allocate other issues and to formulate new questions beyond those that were planned (Hair, et. al., 2005). As source of secondary data, websites, documents and academic articles were used in order to supplement the information obtained through the interviews.

The interview guide was applied to five companies, two Incubated and three Graduated. The studied companies were or are linked to the Centre for Entrepreneurship at the Institute of Informatics (CEI) of the Federal University of Rio Grande do Sul (UFRGS), a technological-based incubator that encourages projects in the area of technology. This choice was made because according to studies of ANPROTEC (2005, 2006), most Brazilian incubators encompass micro and small technology-based companies. The companies were contacted in advance, and in-person interviews with the directors of each one of them were conducted from the outline mentioned earlier during the months of June and July $20 \mathrm{I} \mathrm{I}$.
Seeking greater reliability for data analysis, we used a technique called triangulation, which is the combination of multiple intersections and points-of-view through the joint work of multiple researchers, informants, and techniques of data collection (Minayo, 1993). In this study, three researchers conducted their analysis of the interviews separately and independently. After this stage, meetings were held, in which the contents of each interview were discussed in order to seek common and divergent points.

For data evaluation we used the technique of "content analysis" (Bardin, 2006). This technique requires the creation of analysis' categories, which were previously defined in this study based on a theoretical background. The analysis' categories and theoretical background used to support them are summarized in Table I.

After we had presented methodological approaches, the results of this research are discussed on the following section.

\section{Analysis}

The analysis was based on the differentiation between Incubated and Graduated companies. As discussed above the term "Incubated" is used here to characterize companies

\begin{tabular}{|c|c|c|c|}
\hline \multirow{2}{*}{ Macro } & \multicolumn{2}{|c|}{ Micro } & \multirow[b]{3}{*}{$\begin{array}{l}(1990) . \\
\text { inter (2000). } \\
(2008) . \\
(2005) . \\
2)\end{array}$} \\
\hline & Categories & Subcategories & \\
\hline 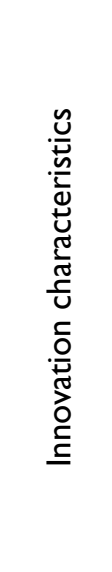 & $\begin{array}{l}\text { - Knowledge base (and sources). } \\
\text { - R\&D structure and capabilities. } \\
\text { - Relationships (network). } \\
\text { - Relation with university. } \\
\text { - Alignment between R\&D and } \\
\text { MKT sectors. } \\
\text { - Innovation strategy. }\end{array}$ & $\begin{array}{l}\text { - } \\
\text { - Partnerships for qualification } \\
\text { - Alliances/Partnerships } \\
\text { - Participating in associations } \\
\text { - Projects with University } \\
\text { - Use of University labs } \\
\text { - } \\
\text { - Innovation Stimulus }\end{array}$ & \\
\hline 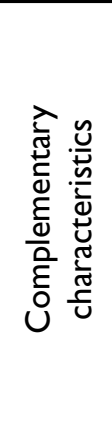 & $\begin{array}{l}\text { - Marketing structure and capa- } \\
\text { bilities. } \\
\text { - Institutional environment (val- } \\
\text { ues, rules, beliefs, etc.). } \\
\text { - Opportunity identification } \\
\text { (consumer needs). } \\
\text { - Price definition. } \\
\text { - Relation with costumers. } \\
\text { - Complementary strategy. }\end{array}$ & $\begin{array}{l}- \\
- \\
-\end{array}$ & $\begin{array}{l}\text { - Cabral (200I; 2007). } \\
\text { - Christensen (1995). } \\
\text { - Dosi, Nelson and Winter (2000). } \\
\text { - Freeman and Soete (2008). } \\
\text { - Teece (1986). } \\
\text { - Williamson (1985). }\end{array}$ \\
\hline
\end{tabular}

Table I.Analysis' categories

ISSN: 07 I8-2724. (http://www.jotmi.org)

Journal of Technology Management \& Innovation (C) Universidad Alberto Hurtado, Facultad de Economía y Negocios. 
that are in the incubation process which the main purpose is offer to entrepreneurs the necessary infrastructure and strategic support for the development of their activities. On the other hand, "Graduated" are that companies which already have gone through this stage. Some basic information about the companies studied is presented in Table 2.

In order to develop the analysis, we tried to observe the general characteristics of the structure of the companies studied in order to verify how they evolve in the pursuit of innovation and development of the firm.

\section{I The Incubated companies}

The Incubated A was founded in middle of 2008 in Porto Alegre, in southern Brazil, with support from LAMEF (Laboratory of Physical Metallurgy) belonging to UFRGS and CEI, with the goals of: (I) providing high technology to robotics and inspection sectors; (2) improvement of programs for equipment maintenance; and (3) total inspection and analysis of areas with propensity for propagation of faults. The company also develops systems for security area, providing specialized equipment for handling explosives.

The Incubated B, on the other hand, is a Brazilian company that develops, manufactures, and markets products and solutions based on RFID (Radio Frequency Identification). Began its activities in 2007, already focused on RFID and since then has specialized in different patterns (LF, HF and UHF) that open up business opportunities in different market segments.

The Incubated companies have up to 10 employees and most of them has come from engineering sector and are involved in product development. For both companies the administrative area turns out to be a secondary concern due to low number of employees. A single person also takes on the business function and other activities, as one of the directors of Incubated B remind us:"The two partners share the tasks. One is left with the commercial and administrative tasks and the other with the technical ones". The same happens with R\&D area, which is not quite structured, although most employees are allocated to product development based on their technical background.
In regards to the commercial sector both companies does not have a specific structure to perform these activities and in the two companies studied marketing functions are performed by one of the partners. When asked about the commercial sector, the director of Incubated A has stressed:"Do you want to speak with the sales department? You're talking to him! When the company is small, you sell, you project, you sweep the floor, and you do everything. [...] We adapt technologies according to the needs of each client in a specific way". The definition of the sale price, in both cases, is made based on market due to the specificity of assets developed. The disclosure occurs mainly through direct contact of the owners with potential customers. Both companies use internet, websites and e-mails to promote their products, but each company has some particularities in searching for new clients: Incubated A participates in fairs, conferences and business roundtables, while Incubated B makes use of specialized magazines and the service of resellers. The customer service of Incubated A is informal (conducted by e-mail), and in the case of Incubated $B$ there is no specific sector for this activity (the dealer provides technical support for the end customer).

Regarding the relationship with other organizations, we observed in the two cases studied a preference for qualification relations. The Incubated A makes use of professional courses offered by SEBRAE (Brazilian System to support micro and small enterprises), that according to the respondent "opens significantly the array of contacts" of the company. The Incubated B, by its turn, uses the services of consulting firms, some having been contacted using the relationship with the incubator, and others externally, in order to meet specific needs. Both companies recognizes as key stakeholders customers, suppliers and sales representatives and both did not participate in any kind of association.

All the Incubated companies studied view their employees as the main source of knowledge, operating as a link between them and the University. The Incubated A, however, has shown more interaction with the university, making broader use of available resources (e.g. laboratories) and having projects with university, which is also one of its customers. They also define "innovation" in a similar way, as a solution to market problems (troubleshooting). While for the director of Incubator A "it corresponds to create a solution or a

\begin{tabular}{|c|c|c|c|c|c|}
\hline & Incubated A & Incubated B & Graduated A & Graduated B & Graduated C \\
\hline Foundation & 2008 & 2007 & 1999 & 1997 & 1998 \\
\hline Graduation & - & - & 2003 & 1999 & 2000 \\
\hline Product & Robotics & $\begin{array}{c}\text { Radio Frequen- } \\
\text { cy Identification } \\
\text { (RFID) }\end{array}$ & $\begin{array}{c}\text { Solutions with } \\
\text { biometric tech- } \\
\text { nology }\end{array}$ & $\begin{array}{c}\text { Industrial Auto- } \\
\text { mation }\end{array}$ & $\begin{array}{c}\text { Educational man- } \\
\text { agement software }\end{array}$ \\
\hline
\end{tabular}

Table 2. Information about the companies surveyed.

ISSN: 07 I8-2724. (http://www.jotmi.org)

Journal of Technology Management \& Innovation (c) Universidad Alberto Hurtado, Facultad de Economía y Negocios. 
product that solves an existing problem, speeding up or facilitating a person's life", for the director of Incubated B "it's solving a problem that exists in the market in a way that no one has solved before". Regarding innovation strategies, it was observed different positioning: while the Incubated B focus on specific market niches and incremental changes in its products, the Incubated A invests in product adaptation with a slight interaction between commercial and R\&D sectors.

Finally, in both companies the innovation stimulus is put into the background, with no kind of bonus or profit sharing for the employees. But while Incubated A tries to encourage their employees to seek innovative solutions (even in a subjective way), there is no kind of stimulus in the Incubated B. Perhaps due to a stronger interaction with the University, Incubated A has showed greater concern with innovation, encouraging their employees to seek innovative solutions, which did not occur in Incubated B. Such assumption can be strengthened by the fact that Incubated $A$ has more patents (four) and considers this procedure important. Incubated B has only one patent, and does not see any advantage in this practice.

\subsection{The Graduated companies}

The Graduated A, founded in 1999, is a technology-based company specialized in products and solutions with biometrics (fingerprint scanning). Among its major projects there is the development of electronic voting machines for the Electoral system of Brazil.

Based in Porto Alegre, the Graduated B is a company focused on the areas of factory automation and image processing. The company develops technologies for vision systems, cameras that replace the human eye in quality control of products, border surveillance and monitoring of the movement of persons. Among its projects, the Graduated B developed a vision system that selects and ranks fruit by color, size and degree of maturity at a rate of up to 72,000 fruit $/ \mathrm{h}$ where every fruit is inspected throughout its circumference, and analyzed three photos shifted by 120 degrees relative one to another.

The Graduated C, in its turn, develops software for educational management of schools and universities. The company buys development tools and database handler from companies like Microsoft and Embarcadero in order to develop technology for school management. With 12 years of activity, the company serves various educational institutions, which together educates more than 100,000 students per year.

The Graduated companies have 20 to 30 employees. Due to the growth of the organization and contact with the market without intervention of the University, it was observed in all Graduated the need for formal controls - as well as the standardization of some processes. Although possessing employees with ties to university, the Graduated companies studied have demonstrated a trend of detachment from the educational institution where they were formed through the incubation process. Except for Graduated B, in which the Director stated hold some joint projects with the university, none of the other has or had any type of project with the university after graduation or even uses university laboratories.

The companies studied have different stances on relationships with other organizations: (I) Graduated A has partnerships with both commercial software vendors as hardware manufacturers; (2) Graduated B besides having as trading partners hardware manufacturers also participates in different associative sector entities; and (3) Graduated C, in turn, has partnerships for qualification (in business and education management) with consultancy firms and has as other partners software vendors and government agencies. Additionally, Graduated $C$ is recognized by the foundation ABRINQ as "child-friendly company" and supports the federal government's project "Education for all", a Brazilian civil society movement that has the mission of contributing to that by 2022, bicentennial of the Independence of Brazil, the country ensures all children and young people the right to quality basic education.

Both initiatives of Graduated C - with the proximity of initiatives focused on education - and Graduated B by participating in the associative sector entities, gives these companies certain "institutional legitimacy" in the sector in which they operate, providing them the opportunity to reduce their transaction costs (Williamson, 1985). The alliances developed by the Graduated companies also contribute to increase the innovative capacity of the firms (Cabral, 2007) and is an important consequence of the expansion of its relationships network (Powell and Grodal, 2005).

With respect to the sale price, in all companies studied this is defined based on the market due to the specificity of assets developed. Furthermore, the strategy of innovation presented by Graduated companies proved to be similar. In all companies the commercial sector identifies market opportunities and transmits them to the R\&D sector, which develops the solutions. Additionally, employees are encouraged in the development of these innovative solutions: while in Graduated A and B there is a subjective innovation stimulus in Graduated $C$ it occurs through profit sharing. 


\subsection{Graduated and Incubated compared: a strength- ening of the firm?}

A comparative analysis between the two types of companies studied (Graduated and Incubated) brings out similarities and differences, as showed in Table 3 . In both groups, it is possible to observe a consensus on certain additional features such as: (I) clearly market identification in which firms are embedded, i.e. opportunities, barriers to entry and competitors (Freeman and Soete, 2008); and (2) the sale price definition. While in the former case the support offered by incubation process may have had a considerable influence, in the last case is not possible to observe an aspect that may differ significantly the studied companies from those that have never been in an incubator.

We could observe other similarities between Graduated and Incubated with respect to some innovation's characteristics, although there was no consensus among the companies studied. Most companies studied do not use the structure offered by the university, specially its laboratories. For
Graduated enterprises, this behavior may be explained by the detachment in terms of interests or by the company's internal structure evolution - that made needless the displacement until the university to make use of a structure which the company itself can provide. For Incubated companies, on the other hand, especially in the case of Incubated $B$, this strategic position may reflect some difficulty faced by the company, or even a failure in the incubation process. By observing the differences between the incubated companies, especially in terms of innovation strategies and patents registry, protrudes the benefits from proximity to the university during the incubation process. That is, given the importance of this relationship, it becomes imperative to understand what the real magnitude of discrepancy between Incubated companies: Could be significant the number of companies apart from the structure of the university during the incubation process? Here there is a possibility for further studies.

Another aspect that draws attention is the lack of clear mechanisms for stimulating innovation. Except for Graduated $\mathrm{C}$, which offers financial benefits for their employees

\begin{tabular}{|c|c|c|c|c|c|c|}
\hline & & INC (A) & INC (B) & GRAD (A) & GRAD (B) & GRAD (C) \\
\hline \multirow{9}{*}{ 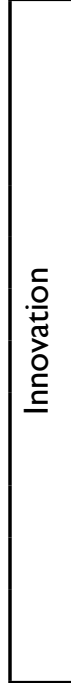 } & I. Knowledge base (and sources) & $\begin{array}{l}\text { Employees; } \\
\text { University. }\end{array}$ & $\begin{array}{l}\text { Employees; } \\
\text { Internet; Sup- } \\
\text { pliers; Com- } \\
\text { petitors. }\end{array}$ & Employees & Customers & $\begin{array}{l}\text { Customers; } \\
\text { Competitors; } \\
\text { Legislation }\end{array}$ \\
\hline & 2. R\&D sector & Not Structured & Not Structured & Structured & Structured & Structured \\
\hline & 3. Partnerships for qualification & Yes & \begin{tabular}{|l|} 
Yes \\
\end{tabular} & No & No & Yes \\
\hline & 4.Alliances/Partnerships & Weak & Weak & Strong & Strong & Strong \\
\hline & 5. Participating in associations & No & No & No & Yes & No \\
\hline & $\begin{array}{l}\text { 6. Alignment between R\&D and } \\
\text { MKT }\end{array}$ & Weak & Weak & Strong & Strong & Strong \\
\hline & 7. Projects with University & Yes & No & No & Eventually & No \\
\hline & 8. Use of University labs & Yes & No & No & No & No \\
\hline & 9. Innovation stimulus & $\begin{array}{l}\text { Informal/Subjec- } \\
\text { tive } \\
\end{array}$ & None & \begin{tabular}{|l|} 
Informal/ \\
Subjective \\
\end{tabular} & $\begin{array}{l}\text { Informal/ } \\
\text { Subjective }\end{array}$ & Profit sharing \\
\hline \multirow{6}{*}{ 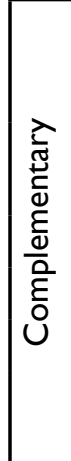 } & $\begin{array}{l}\text { 1. Marketing structure and } \\
\text { capabilities }\end{array}$ & Not Structured & Not Structured & Structured & Structured & Structured \\
\hline & 2. Institutional environment & University & Not Observed & $\begin{array}{l}\text { Govern- } \\
\text { ment }\end{array}$ & $\begin{array}{l}\text { Associa- } \\
\text { tions }\end{array}$ & $\begin{array}{l}\text { Government/ } \\
\text { ONGs }\end{array}$ \\
\hline & 3. Opportunity identification & Yes & Yes & Yes & Yes & Yes \\
\hline & 4. Price definition & Market & Market & Market & Market & Market \\
\hline & 5. Relation with costumers & Informal & Use of dealer & Informal & Informal & Formal \\
\hline & 6. Complementary strategies & $\begin{array}{l}\text { University } \\
\text { nearness }\end{array}$ & Not Observed & $\begin{array}{l}\text { Insights } \\
\text { overseas }\end{array}$ & $\begin{array}{l}\text { Customer } \\
\text { loyalty }\end{array}$ & $\begin{array}{l}\text { Customer } \\
\text { services }\end{array}$ \\
\hline
\end{tabular}

Table 3. Incubated and Graduated companies: some remarks.

ISSN: 07I 8-2724. (http://www.jotmi.org)

Journal of Technology Management \& Innovation (c) Universidad Alberto Hurtado, Facultad de Economía y Negocios. 
as a way to stimulate new ideas, the other companies fail to create any type of system that encourages its employees to continue innovating. With this observation, it is possible to observe that the analyzed companies still need to align their structures in order to promote greater innovation and ensure the firm's survival (Nelson and Winter, 1982; Kim, 1997; Bessant, et. al., 2005; Freeman and Soete, 2008).

However, the similarities between the two types of companies studied end here. The differences are highlighted when we analyze the network or relationships developed by the companies. While in Incubated companies the focus is on qualification relationships in the Graduated ones that focus seems to turn to commercial partnerships. Based on it, we highlight the importance of ties (weak and strong) established by the companies (Granovetter, 1973; Powell and Grodal, 2005). During graduation the companies - mediated by strong ties established between them and the university seek relationships that might improve their capabilities.After graduating the companies started to value the establishment of weak ties with other actors in their midst, searching by means of these expand their business networks.

In other words, once in contact with market, without having support from the university, Graduated companies start struggling to survive in a highly competitive environment and, therefore, must develop new strategies such as the expansion of its range of contacts and relationships. Once being minimally prepared to run their businesses, in first years on the market without the support of the university companies come to worry less about their qualification and more with a more basic task but no less important: the sale of its product. This concern, that is very important to the enterprises, brings to the fore characteristics of the companies' internal structure, or, more specifically, the way that the relationship between the sectors of R\&D and Commercial happens.

Whilst, in Incubated, this relationship is weak or absent, due to the fragility of the internal structure of firms and the allocation of human resources within these (mostly focused on industry R\&D), in the Graduated ones the search for innovation through constant interaction between the R\&D and Marketing sectors is remarkable (Freeman and Soete, 2008). In these companies, there is a clear evolution in the internal structure, with its sectors more structured (i.e. areas are formalized and exhibit well-defined tasks) and aligned, ena- bling Graduated companies to be considered more "firms" that companies that still in the incubation process.

In this way, Graduated companies have shown an evolution of its routines or capabilities (Nelson and Winter, 1982; Prahalad and Hamel, 1990; Leonard-Barton, 1992), changing its own structure in order to adapt itself to the context in which it lives (Amendola, 1983), and somehow renewing the organization itself (Bessant, et. al., 2005) through an innovation strategy based on the interaction between R\&D and Marketing sectors, what requires the use of different "complementary assets" mixed with the companies' technological basis (Teece, 1986; Christensen, 1995; Cabral, 2001;2007) . In other words, it can be said that there is a "strengthening of the firms". Such empowerment can explain a higher survival rate in these companies which have gone through the incubation process (according to data above).

In addition to strengthening the firm and providing essential resources, incubation seems to enable the manager of the company itself, stimulating his spirit of "entrepreneur coordinator" (Schumpeter, 1997), which is able to allocate these resources in a better way than other firm's disposition in the market. Finally, was possible founded a strengthening of the firm after the incubation process in the studied companies (Figure 4).

\section{Final Remarks}

In order to understand what is behind the low mortality rate in Brazilian companies that have gone through the incubation process, this research was carried out to verify the incubation process' contribution to the studied companies, analyzing its role played in the innovation generation and if the incubator would be developing the firm. For this, we developed an interview guide with five companies, two Incubated and three Graduated, in order to compare them and observe the key characteristics derived from the incubation process that are important for their survival in the market. We found similarities and differences between Incubated and Graduated companies. In both groups, we could observe a consensus in certain additional features such as a clear target market identification and price setting. The differences were more pronounced in categories related to the innovation process, such as structuration and interaction between R\&D and Marketing.

\section{Brazilian Companies Incubation Process}

\section{FIRM Innovation process, market interaction, structured R\&D}

Figure 4. The firm and the incubation process.

ISSN: 07 I8-2724. (http://www.jotmi.org)

Journal of Technology Management \& Innovation (c) Universidad Alberto Hurtado, Facultad de Economía y Negocios. 
During the incubation process, the studied companies showed a greater focus on strengthening their knowledge bases, seeking to establish qualification relationships, as well as invest in an innovation strategy founded on better allocation of (scarce) resources. Regarding this, it has been shown to be a beneficial situation for Incubated companies having a greater proximity to the university and a greater use of the resources offered by it. Therefore, the more interaction between the company and the university, the more focused on innovation (and more close to a firm) the company will be. After graduation, companies have to "face the market" without the support from the incubator, it creates the need for a change in the organization (forms of control, departments, physical structure, etc). Moreover, it was observed that after incubation, there is more interaction between the R\&D and commercial departments, which promotes a structured innovation process, where innovation is seen not only as a solitary search for technical evolution, but also as a process of searching for market opportunities. It happens when complementary activities complement the technical background of the company.

Such a change is reflected also in the relationships established by the Graduated companies, which deepen and become more varied after graduation. There is a shift from a focus in company qualification during incubation to a focus on establishing commercial partnerships. The Graduated companies studied also showed greater concern with the institutional environment where they were, searching through participation in associations and government programs for competitive advantage and reduction the transaction costs. So, beyond the need to change its internal structure when entering in the market, firms also change their network of relationships, seeking to narrow its commercial and institutional ties.

In this respect, still remains some doubt about if this "strengthening of the firm" is a result of the incubation process or given by contact with the market. When the Graduated companies have faced the market, they certainly had to seek for all the possible alternatives that might raise their survival chances. But, perhaps they had not had the same luck if they had not expanded their knowledge bases and amplified their internal capacities before entering the market. At this point one could argue that the existence of successful companies in the market that have not passed through the incubator may be the result of them having already developed a basic structure and an "entrepreneur-coordinator" sufficiently trained, that dispense the need to go through the incubation process.

However, for further clarification on this issue, it is important to call for further studies comparing companies that passed through incubation process with those who have not gone through this process, whether successful or unsuccessful. There also remains the doubt of how the initial selection made by the incubator (i.e. choosing which companies would participate in the incubation process) may have been influential. Here is another suggestion for future studies seeking to understand more about the influence in the companies' selection process by incubators.

Among the limitations of this research, it should be noted the impossibility of generalization concerning the obtained results, given the qualitative nature of this study and the sector of the industrial enterprises (technology based). Due to this limitation, it is suggested that future research focus on a quantitative character study that seeks to structure an instrument to measure some dimensions of this process, generating an index that can serve as a benchmark.

It is also suggested to conduct studies to check the rate of detachment between incubated companies and university, once this characteristic was found in this study. Furthermore, it is suggested the expansion and diversification of companies chosen, looking for other sectors of activity besides technology, with the purpose to observe qualifications of the subsidy offered by the incubators.

\section{Acknowledgements}

We would like to thank CAPES for the financial support.

\section{Notes}

I To join the incubator (and the incubation process), companies initially go through a selection process, which consists primarily of the analysis of the business propositions of the enterprise. The incubator chooses the projects with the best characteristics, what includes, for instance, a more detailed analysis of the aspects that are contained in the business plan of the company, if it exists. Companies also go through an auditing process, in which the incubator should find out more about the business which it will be incubating and in which it will have a share. This includes a detailed analysis of the accounts and legal aspects in order to verify the fiscal and contractual situation of the company in order to minimize recurring risks from possible fiscal irregularities, liabilities with labor or clients/suppliers who might jeopardize the company's businesses. Once selected, companies go through the process of incubation, which takes on average two years. After have been graduated the company is considered able to become established outside the incubator infrastructure. 


\section{References}

ABIB, G., Hayashi, P., Asanome, K., Labiak, S. (2007).A eficiência das incubadoras no alinhamento estratégico e mercadológico das empresas incubadas e graduadas: um estudo em quatro incubadoras paranaenses. Seminário Latino-lberoamericano de Gestión Tecnológica. Buenos Aires.

AFUAH,A. (2003). Innovation management: strategies, implementation and profits. Oxford University Press, New York.

AMENDOLA, M. (1983). Un changement de perspective dans l'analyse du processus d'innovation. In: Tournemine, $R$. (Ed.) L'innovation. La Documentation Française, Paris.

Associação Nacional de Entidades Promotoras de Empreendimentos Inovadores - ANPROTEC (2005). Panorama 2005. http://www.anprotec.org.br [Accessed on: May 12th, 20I2].

Associação Nacional de Entidades Promotoras de Empreendimentos Inovadores - ANPROTEC (2006). Panorama 2006. http://www.anprotec.org.br [Accessed on: May 12th, 20I2].

BARDIN, L. (2006). Análise de conteúdo. Edições 70, Lisboa.

BESSANT, J., Lamming, R., Noke, H., Phillips, W. (2005). Managing innovation beyond the steady state. Technovation, 25, |366-1376.

BONOMA, T.V. (1985). Case Research in Marketing: opportunities, problems and a process. Journal of Marketing Research, 22, 199-208.

CABRAL, J., Traill,W. (200I). Determinants of a firm's likelihood to innovate and intensity of innovations in the Brazilian food industry. Journal on Chain and Network Science, Holanda, I, 33-48.

CABRAL, J. (2007). Determinantes da propensão para inovar e da intensidade inovativa em empresas da indústria de alimentos do Brasil. Revista de Administração Contemporânea, I I (4), 87- 108.

Centro Empresarial para Elaboração de Tecnologias Avançadas - CELTA. (20I2). http://www.celta.com.br [Accessed on: May IOth, 20I2].

CHRISTENSEN, J. F. (1995). Asset profiles for technological innovation. Research Policy, 24(5), 727-745.

COASE, R. (1937). The nature of the firm. Economica, 4 (I6), 386-405.
COHEN, W., Levinthal, D. (1990). Absorptive Capacity: A New Perspective on Learning and Innovation.Administrative Science Quarterly, 35, 128-52.

DOSI, G., Nelson, R.,Winter, S. (2000). Introduction. In: Dosi, G., Nelson, R.,Winter, S. (Eds.). The Nature and Dynamics of Organizational Capabilities. Oxford University Press, New York, pp. I-22.

EISENHARDT, K.; Martin, J. (2000). Dynamic capabilities: What are they? Strategic Management Journal, 2I, II05II2I.

ENRIQUEZ, G. (200I). Sistemas locais de inovação tecnológica, incubadoras de empresas e desenvolvimento da indústria do Pará. Revista Saber: Ciências Exatas e Tecnologia, $3,103-120$.

ETZKOWITZ, H., Mello, J., Almeida, M. (2005). Towards “meta-innovation" in Brazil:The evolution of the incubator and the emergence of a triple helix. Research Policy, 34, 4 I I-424.

FAGERBERG, J. (2005), Innovation: A Guide to the Literature. In: Fagerberg, J., Mowery, D.C. and Nelson, R. R. (Eds.), The Oxford Handbook of Innovation, Oxford University Press, New York. pp. I-27.

FREEMAN, C., Soete, L. (2008). A Economia da Inovação Industrial. Editora da UNICAMP, Campinas.

GRANOVETTER, M. (1973). The Strength of Weak Ties. American Journal of Sociology, 78, I360-1380.

HAIR, J.; Babin, B.; Money, A.; Samouel, P. (2005). Fundamentos de métodos de pesquisa em administração. Bookman, Porto Alegre.

Instituto Brasileiro de Geografia e Estatística - IBGE (20I2). Demografia das empresas 2010. http://www.ibge.gov.br [Accessed on: November 7th, 2012].

Instituto Brasileiro de Planejamento Tributário - IBPT (20I2). Empresômetro: censo das empresas e entidade públicas e privadas brasileiras. http://www.ibpt.com.br/img/_publicacao/ 14322/203.pdf [Accessed on: November 6th, 2012].

KIM, L. (I997). Da Imitação à Inovação. Editora da UNICAMP, Campinas.

LANGLOIS, R.N. (2003). The Vanishing Hand:The Changing Dynamics of Industrial Capitalism. Industrial and Corporate Change, 12 (2), 35 I-385. 
LEONARD-BARTON, D. (1992). Core capabilities and core rigidities: A paradox in managing new product development, Strategic Management Journal, I 3, I I I- 125.

MARINS, L. M. (2007). Economia, Tecnologia e Inovação: da Teoria da Firma à Gestão da Inovação Tecnológica, Revista Eletrônica de Ciência Administrativa, 6(I), I-I4.

MINAYO, M. C. S. (1993). O desafio do conhecimento: pesquisa qualitativa em saúde. Hucitec, São Paulo.

National Business Incubation Association - NBIA (20II). http://www.nbia.org [Accessed on: May 10th, 20I2].

NELSON, R., Winter, S. (1982). An Evolutionary Theory of Economic Change. The Belknap Press of Harvard University Press, Cambridge.

Office for National Statistics - ONS (2012). Business Demography 2010. http://www.ons.gov.uk/ons/rel/bus-register/business-demography/20 I0/stb---business-demography-20 I0.html [Accessed on: November 5th, 20I2].

PENROSE, E. (1959). The Theory of the Growth of the Firm. Oxford University Press, New York. Reprinted in 1995.

POWELL,W., Grodal, S. (2005). Networks of Innovators. In: Fagerberg, J., Mowery, D.C., Nelson, R. R. (Eds.), The Oxford Handbook of Innovation, Oxford University Press, New York. pp. 56-85.

PRAHALAD, C., Hamel, G. (1990). The core competence of the corporation. Harvard Business Review, 68 (3), 79-90.

RICHARDSON, G. (1972). The organization of industry. Economic Journal, 82 (327), 883-896.

SCHUMPETER, J. (1997). A Teoria do Desenvolvimento Econômico. Nova Cultural, São Paulo.

SELZNICK, P. (1957). Leadership in administration: a sociological interpretation. University of California Press, Berkeley and Los Angeles. Reprinted in 1984.

TEECE, D. J. (1986). Profiting from technological innovation: implications for integration, collaboration, licensing and public policy. Research Policy, I5(6), 285-305.

TEECE, D. J., Pisano, G., Shuen,A. (1997). Dynamic capabilities and strategic management. Strategic Management Journal, 18(7), 509-533.

TIDD, J., Bessant, J., Pavitt, K. (2005). Managing Innovation: Integrating Technological, Market and Organizational Change. John Wiley \& Sons Ltd, Chichester.
U.S. Department of Labor, Bureau of Labor Statistics (2012). Entrepreneurship and the U.S. Economy. http://www.bls.gov/ bdm/entrepreneurship/bdm_chart3.htm [Accessed on: November 6th, 2012].

WILLIAMSON, O. E. (1985). The Economic Institutions of Capitalism: Firms, Markets, Relational Contracting. Free Press, New York.

WILLIAMSON, O. E. (1996). Economics and organization: A primer. California Management Review, 38(2), I3I-I 46.

YIN, R. K. (20I0). Estudo de caso: planejamento e métodos. Bookman, Porto Alegre.

ZAWISLAK, P. (1995). A relação entre conhecimento e desenvolvimento: essência do progresso técnico. Análise, 6 (I), 125-149.

ZAWISLAK, P. (2004). Nota técnica. In: Clegg, S.; Hardy, C; Nord, D. (Eds.) Handbook de estudos organizacionais. Atlas, São Paulo. pp. 180-185.

ZAWISLAK, P., Alves, A., Gamarra, J., Barbieux, D., Reichert, F. (20I2). Innovation Capability: From Technology Development to Transaction Capability. Journal of Technology Management \& Innovation, 7, 14-27. 